\title{
O TURISMO RELIGIOSO E O PROCESSO DE COMUNICAÇÃO DE MARKETING: UM ESTUDO DO SANTUÁRIO DE SANTA PAULINA EM NOVA TRENTO - SC
}

RELIGIOUS TOURISM AND THE PROCESS OF MARKETING COMMUNICATION: A STUDY OF THE SANCTUARY OF SANTA PAULINA IN NOVA TRENTO - SC

EL TURISMO RELIGIOSO Y EL PROCESO DE COMUNICACIÓN DE MARKETING: UN ESTUDIO SOBRE EL SANTUARIO DE SANTA PAULINA EN NOVA TRENTO - SC

\section{Carlos Marcelo Ardigó}

Docente do Programa de Pós-Graduação Stricto Sensu - Mestrado e Doutorado em Turismo e Hotelaria e Coordenador do Curso de Administração Universidade do Vale do Itajaí - UNIVALI marcelo.ardigo@univali.br

\section{Leticia Caetano}

Graduanda em Publicidade e Propaganda - UNIVALI leticiapp2010@hotmail.com

\section{Lílian Paula Damo}

Graduanda em Publicidade e Propaganda - UNIVALI liliandamo@hotmail.com

Data de submissão: 20/10/2015 Data de aprovação: 18/03/2016

RESUMO: A comunicação de marketing desempenha um papel crucial no que infere a formação da imagem que os turistas e os potenciais turistas apresentam de um determinado destino. Para tal, este estudo se propôs a analisar o processo de comunicação de marketing junto aos visitantes do 
Santuário Santa Paulina, localizado na cidade de Nova Trento/SC. A pesquisa realizada descreveu o perfil do anunciante e o público-alvo, identificou os meios e as mensagens transmitidas e avaliou os impactos provocados pela comunicação do turismo religioso em relação ao receptor. De cunho exploratório descritivo com abordagem quali-quantitativa, fez uso do procedimento triplo, incluindo a entrevista em profundidade, a observação e o método survey. No caso deste último procedimento, utilizou-se uma amostra não probabilística formada por 162 observações. Os resultados apontaram que existe uma lacuna em nível moderado entre como a comunicação é emitida e recebida e, caso seja adaptada, ela pode se tornar mais precisa, evidente, fortalecida e unificada.

PALAVRAS-CHAVE: Processo de comunicação. Comunicação de Marketing. Turismo religioso.

ABSTRACT: marketing communication plays a crucial role in inferring the image that tourists and potential tourists have of a particular destination. This study therefore analyzes the process of marketing communication among visitors to the Sanctuary of Santa Paulina, located in Nova Trento, in the state of Santa Catarina. The research describes the profile of the advertiser and the target audience, identified through messages transmitted, and evaluates the impacts caused by the communication of religious tourism on the target audience. This is a descriptive exploratory study, which uses qualitative and quantitative approaches, using the triple procedure, including in-depth interviews, observation and the survey method. In the case of this latter procedure, a nonprobablistic sample consisting of 162 observations was used. The results showed that there is a gap between how moderate level communication is sent or received. If it is adapted, it can be made more accurate and clearer, becoming more unified and strengthened.

KEYWORDS: communication process. Marketing Communications. Religious tourism.

RESUMEN: La comunicación de marketing desempeña un rol crucial en lo que se refiere a la formación de la imagen que los turistas y los potenciales turistas presentan de un determinado destino. Con esa finalidad, este estudio se propuso analizar el proceso de comunicación de marketing con los visitantes del Santuario Santa Paulina, ubicado en la ciudad de Nova Trento/SC. La investigación realizada describió el perfil del anunciante y del público destinatario, identificó los medios y los mensajes transmitidos y evaluó los impactos provocados por la comunicación del turismo religioso en relación al receptor. De cuño exploratorio descriptivo con un enfoque cualitativo y cuantitativo, el estudio hizo uso del procedimiento triple, incluyendo la entrevista en profundidad, la observación y el método survey. En el caso de este último procedimiento, se utilizó una muestra no probabilística formada por 162 observaciones. Los resultados señalaron que existe una brecha a nivel moderado entre cómo la comunicación es emitida y recibida, y en el caso de que sea adaptada, se podría volver más precisa, evidente, fortalecida y unificada.

PALABRAS CLAVE: Proceso de comunicación. Comunicación de Marketing. Turismo religioso.

INTRODUÇÃO

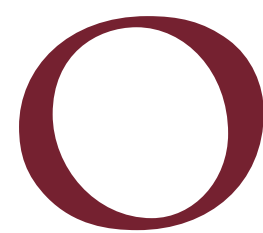
turismo religioso vem crescendo muito nos últimos anos e tem grande importância no desenvolvimento econômico, cultural e social (CARVALHO; VIANA, 2014) de diferentes regiões do Brasil e do mundo. Em vista disso, este segmento envolve negócios, empreendimentos, 
mercado de trabalho e opções de lazer (CACHO; AZEVEDO, 2010; DRULE et al., 2012). No que se refere à propagação da fé no mercado turístico, a motivação dos indivíduos é o principal aspecto que incentiva o visitante a ter necessidade de conviver e conhecer culturas religiosas (IAPICHINO, 2010; FERREIRA; SANTOS, 2010; DE LA TORRE; NARANJO; CARDENAS, 2012).

Desse modo, objetiva-se a realização de visitas a locais que transmitam o sentimento de peregrinação e demonstração de fé, por meio de romarias ou peregrinações, ou pelo interesse em adquirir conhecimento de uma determinada cultura religiosa, visitando-se templos, santuários, lugares histórico-culturais ou até mesmo realizando rituais ou participando de eventos característicos de uma religião (JALUSKA; JUNQUEIRA, 2012).

Entre os destinos procurados nesse segmento, o Santuário Santa Paulina, localizado na cidade de Nova Trento, em Santa Catarina, é um exemplo desse fenômeno. Após a beatificação de Madre Paulina, e sua canonização, em maio de 2002 pelo Papa João Paulo II, a cidade, que já possuía uma relação com a religiosidade, passou a receber um número crescente de peregrinos de todo o país e do exterior. Assim como o santuário e a própria cidade de Nova Trento, muitas regiões buscam estratégias que promovam os destinos turísticos, entre elas as que visam ao desenvolvimento da imagem local junto a seu públicoalvo, estando relacionado com as estratégias de comunicação (AVRAHAM; KETTER, 2007; MTUR, 2010; RICHARD; TELFER, 2015). Para Ruschmann (2000, p. 43), a comunicação alcança seu resultado, ou seja, é eficaz quando "[...] o comunicador (emissor) consegue detectar os gostos e as preferências das pessoas (receptores), criando imagens que as influenciem favoravelmente, estimulando-as a viajar para uma destinação específica". O sucesso depende de como as mensagens são transmitidas e de quais canais são utilizados.

Baseado nestes elementos, este estudo apoiou-se na seguinte questão: como está estabelecido o processo de comunicação de marketing do Santuário Santa Paulina em relação ao público visitante? Direcionado ao atendimento deste, o objetivo geral visou analisar o processo de comunicação de marketing junto ao visitante do Santuário Santa Paulina. Sua operacionalização ocorreu por meio de três etapas específicas, incluindo a descrição do perfil do emissor 
e do receptor; a identificação dos meios e das mensagens transmitidas; e da avaliação dos impactos provocados pela comunicação no turismo religioso em relação ao receptor.

Diante da conjuntura exposta, optou-se em estudar especificamente o turismo religioso para entender como o processo de comunicação de marketing se dá nesse segmento. Além do processo de comunicação, o estudo trouxe informações que podem contribuir para a comunidade acadêmica, servindo como base para futuros trabalhos relacionados principalmente ao turismo religioso. A pesquisa realizada foi de cunho exploratório e descritivo, com abordagem quali-quanti, com procedimento triplo, incluindo a entrevista em profundidade, a observação e o survey. A coleta de dados ocorreu em duas fases: a primeira por meio de materiais e entrevista com representantes do Santuário Santa Paulina e com uma amostra de 162 turistas e visitantes que estiveram no destino.

A estrutura deste trabalho está organizada em cinco seções. A primeira compreende a introdução, com uma breve contextualização a respeito da temática, pergunta e objetivos a serem atingidos. Na sequência é abordada a fundamentação teórica. Posteriormente apresenta a metodologia, seguida da análise dos dados e das considerações finais desta investigação.

\section{O TURISMO RELIGIOSO}

O setor religioso vem crescendo a cada dia e com isso influenciando diretamente a economia do local. Apesar de suas consequências benéficas, se planejado de maneira errada, pode acarretar sérios danos à localidade, como poluição, exclusão social, aumento da prostituição, entre outras problemáticas (TRIGO, 2007). Entre as suas possibilidades, o mercado turístico é considerado uma importante fonte de desenvolvimento (RIBEIRO, 2003; CARVÃO, 2010; SHARPLEY; TELFER, 2015), podendo ser assumido como um tipo de economia (LAGE; MILONE, 2000). Seu funcionamento incorpora os agentes econômicos, turistas ou consumidores de bens e serviços relacionados de forma direta ou indireta com a atividade turística, e as empresas ou produtos destes recursos. 
Dentre as modalidades que abrangem o setor do turismo, o segmento religioso destaca-se por apresentar características que coincidem com o turismo cultural. Devido à visita que ocorre num entorno considerado como patrimônio cultural, os eventos religiosos constituem-se em expressão cultural de determinados grupos sociais ou expressam uma realidade histórica expressiva e representativa de determinada região (DIAS, 2003). Entretanto, ressalta-se que as motivações não são exclusivamente culturais, pois quando se trata de turismo religioso, as motivações religiosas também devem estar delineadas.

Em relação ao âmbito estratégico do turismo religioso, Refkalefsky (2012) afirma que o marketing para uma instituição religiosa significa a troca de valores simbólicos com o ambiente, na medida em que a organização se desenvolve. Não se trata apenas de incorporar valores folclóricos, mas de adaptações na essência de práticas e doutrinas. Assim, o turismo religioso configura-se como uma atividade realizada por pessoas que se deslocam por motivos e eventos de significado religioso ou para vivenciar locais religiosos que contenham valor histórico, cultural e que expressem alguma singularidade da localidade.

\section{O MARKETING TURÍSTICO E O COMPORTAMENTO DO}

CONSUMIDOR

O marketing possui um importante conjunto de ferramentas para as organizações, com um escopo abrangente para vários outros tipos de segmentos. A American Marketing Association (AMA, 2014) estabeleceu em 2007 que o marketing pode ser definido como uma função da organização e um conjunto de processos para criação, comunicação e entrega de ofertas para gerar valor para os clientes, parceiros e sociedade em geral.

Desta forma, o marketing vem ganhando credibilidade e importância não somente com as áreas privativas de consumo em massa, mas também junto aos setores básicos da atividade industrial, por meio do marketing político, religioso, agrícola, de negócios e de serviços (COBRA, 1997). Ademais, o autor afirma que o marketing não é somente um criador de hábitos de consumo, mas sim estimulador da compra de produtos e serviços que satisfaçam. Logo, nota- 
se que o marketing busca como objetivo identificar e satisfazer as necessidades dos consumidores (KOTLER, 2009) e assim conquistar a sua confiança.

Vaz (1999) e Middleton (2002) afirmam também que o marketing tem a finalidade de satisfazer necessidades por meio de um conjunto de atividades econômicas em torno de produtos turísticos, sendo ele um mecanismo de ligação da oferta com a demanda, possuindo forte ênfase nas trocas entre os agentes que atuam direta ou indiretamente no mercado turístico.

Conhecer e entender o comportamento do consumidor é decisivo para o êxito da atividade no marketing turístico, pois com base no comportamento pode-se compreender o que leva o turista a consumir. Esta área de estudo em marketing consiste nas atividades diretamente envolvidas na obtenção, no consumo e na distribuição de produtos e serviços, incluindo os processos de tomada de decisão de compra ou de serviço (OLIVEIRA, 2007; SOLOMON; RIBEIRO, 2011). Corroborando com essa linha de interpretação, Swarbrooke e Horner (2002) propõem que, para a eficácia do processo de marketing, se faz necessário compreender o motivo da escolha de determinados produtos e serviços pelos consumidores e seus benefícios, o que permitirá um posicionamento correto do produto.

De acordo com Vaz (1999), as fontes motivadoras podem ser de diferentes cunhos, como: pessoal, em que se deseja fazer turismo para conhecer determinada localidade, experimentar um transporte novo (avião, por exemplo), ou até mesmo para poder receber um tratamento diferenciado em casos de saúde; familiar, cujo motivo pode ser visitar os parentes distantes; social, leva a pessoa a viajar por suas obrigações sociais, por fazer parte de um grupo ou associação; e organizacional, quando se faz parte de uma empresa que define viagens a negócio, tornando este ato um compromisso.

Já Morrison (2012) afirma que compreender como os consumidores individuais se comportam é um pré-requisito para um marketing eficaz. Isso porque fatores pessoais incluem necessidades, desejos e motivação, percepção, aprendizagem, personalidade, estilo de vida e autoconceito. Já as influências interpessoais são provenientes de culturas, grupos de referências, classes sociais, formadores de opinião e da família. O consumidor coloca mais peso nas recomendações que recebem de amigos e associados do que o fazem com a informação fornecida pelas organizações de hospitalidade e turismo. 
Segundo Middleton (2002), as influências internas e psicológicas que afetam as escolhas individuais são comumente conhecidas como motivação. O emissor precisa compreender o motivo pelo qual alguns produtos ou serviços em particular são preferidos ou rejeitados, e um entendimento das motivações que afetam as escolhas será, em geral, mais importante do que medir os determinantes. O mesmo espera influenciar nas escolhas por meio de informações, marcas, promoções e outras decisões do mix de marketing.

\section{A COMUNICAÇÃO NO TURISMO}

De acordo com Ruschmann (2000), a comunicação no marketing é todo e qualquer esforço realizado para persuadir as pessoas a comprar determinado produto ou serviço. No turismo, a comunicação com o público constitui uma tarefa bastante complexa, uma vez que ela deve ser dirigida a um grande número de pessoas em regiões ou países diferentes. Na comunicação do turismo, deve-se considerar o processamento das informações que o turista recebe e como elas são compreendidas. Essa compreensão inclui todos os aspectos da informação percebida, observando como o visitante desenvolve os conceitos descritivos do produto. Dessa forma, os objetivos da comunicação do turismo devem ser formulados de acordo com a natureza do produto e sua principal meta situa-se no aumento de fluxo de visitantes para determinado destino.

Para compreender os elementos fundamentais da comunicação eficaz, a Figura 1 apresentada por Kotler e Keller (2012) representa um macro modelo com os nove principais elementos do processo de comunicação. Segundo os autores, o emissor precisa saber quais públicos deseja atingir e que reações pretende gerar. Deve-se, a partir disto, codificar a mensagem para que o públicoalvo a decodifique. Além disso, precisa também transmitir a mensagem por meios que alcancem o público e desenvolver canais de feedback para monitorar suas respostas. Quanto mais o campo de experiência o emissor se sobrepõe ao do receptor, mais eficaz será a comunicação. 
Figura 1 - Modelo do processo de comunicação

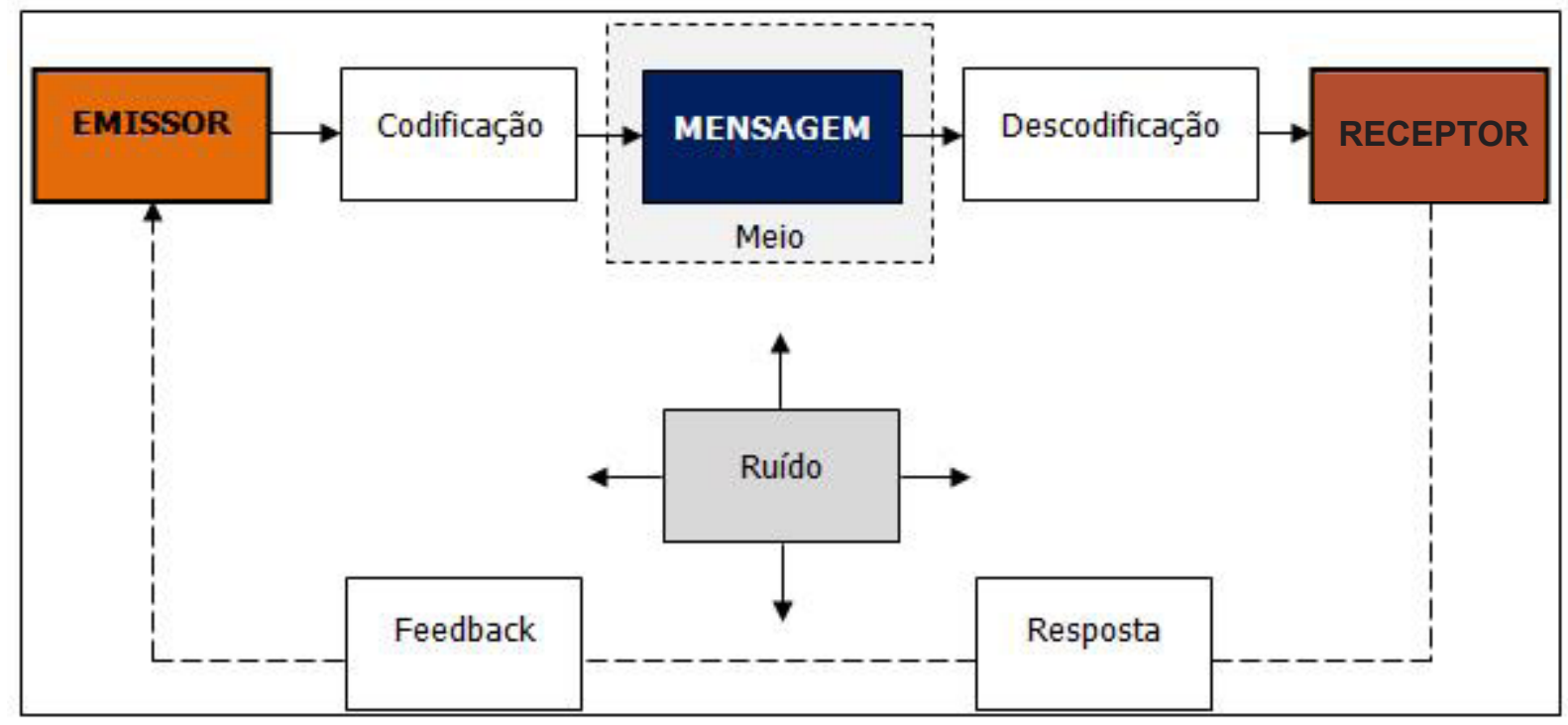

Fonte: Kotler e Keller (2012, p. 358)

Pinheiro (2000) também afirma que, por meio deste canal de comunicação, é possível atingir com uma mensagem uma fonte receptora que procederá a uma interpretação do que recebeu e retornará o entendimento para a fonte. $\mathrm{Na}$ comunicação, quando a fonte emite uma mensagem, ela o faz por meio de códigos. São elementos codificados, interpretados e entendidos (ou não) pelo receptor e devolvidos para o emissor corretamente ou, às vezes, incorretamente. Além disso, outros fatores externos interagem com o sistema e acabam provocando a conhecida interferência, mais popular como "ruído" da comunicação.

Segundo Kotler e Keller (2012), para obter uma resposta desejada, requer-se soluções em três frentes: a estratégia da mensagem - em que a gerência deve procurar apelos, temas e ideias que se conectem ao posicionamento da marca e ajudem a estabelecer pontos de paridade e pontos de diferença; a estratégia criativa - como a mensagem é expressa, assim como conteúdo da mensagem em si; e, por fim, a fonte da mensagem - de forma que sejam atraentes ou famosas e que chamam mais a atenção e sejam lembradas com mais facilidade.

Para alcançar os objetivos propostos, Morrison (2012) afirma que é necessário um esforço da comunicação integrada por parte dos produtores turísticos (empresas hoteleiras, restaurantes, agências de viagem, entre outros) que deverão utilizar técnicas de relações públicas, promoções de vendas e 
propaganda. Isto consiste no conjunto articulado de esforços, ações, estratégias e produtos de comunicação, planejados e desenvolvidos por uma empresa ou entidade, com o objetivo de agregar valor à marca ou de consolidar sua imagem junto a públicos específicos.

\section{METODOLOGIA}

Quanto ao tipo de pesquisa realizada neste trabalho, inicialmente os objetivos assumiram uma tipologia exploratória e descritiva, provendo critérios e maior entendimento sobre a natureza geral de um problema, assim como descrevendo especificidades ou funções do mercado (AAKER; KUMAR; DAY, 2004; MALHOTRA, 2006). A abordagem de pesquisa refere-se tanto a dados qualitativos quanto quantitativos. De acordo com Malhotra (2006, p. 154), "a pesquisa qualitativa proporciona melhor visão e compreensão do contexto do problema, enquanto a quantitativa procura quantificar os dados e, normalmente aplica alguma forma de análise estatística".

Com intuito de aprofundamento, parte dos dados qualitativos ocorreu por meio da observação, via análise de conteúdo, oriundo de mensagens de anúncios, artigos de jornal, programas áudio visuais, dentre muitos outros, utilizados pela organização promotora das mensagens analisadas neste estudo (MALHOTRA, 2006). De acordo com Bardin (2009), este tipo de análise é uma técnica que permite, de forma prática e objetiva, produzir inferências do conteúdo da comunicação de um texto, replicáveis ao seu contexto social. Sendo assim, foi possível identificar os elementos centrais registrados nas peças publicitárias do santuário, utilizando como variáveis de análise os elementos emissor, receptor, meio, mensagem e resposta - que compõem o processo de comunicação, já referenciado anteriormente, com base em Kotler e Keller (2012). O formato metodológico deste trabalho também dispôs de uma entrevista em profundidade, com a finalidade de explorar em detalhes o assunto-objeto, indagando questões pertinentes a um sujeito que detém informações de interesse do estudo (AAKER; KUMAR; DAY, 2004). Outro procedimento de pesquisa foi o método Survey, obtendo informações e fazendo as descrições sobre o público visitante do Santuário Santa Paulina. 
Em relação à entrevista, foi selecionado um representante do Santuário Santa Paulina, que é o responsável pela assessoria do Santuário. A entrevista ocorreu no dia 26 de setembro de 2014, guiada por roteiro estruturado que também levou em consideração as variáveis do modelo do processo de comunicação. A entrevista em profundidade foi aplicada com finalidade de explorar em detalhes o assunto-objeto (AAKER; KUMAR; DAY, 2004). Esta técnica constitui levantamento de dados primários e sua realização se deu por meio de material estruturado, no qual um roteiro foi preestabelecido e formulado com antecedência, (PRODANOV; FREITAS, 2013).

O survey teve sua aplicação por meio de questionário. Seu desenvolvimento teve como base o modelo do processo de comunicação, com questões que permitiam relacionar os dados com o mesmo. Foram introduzidas também perguntas que permitiram a caracterização geográfica e demográfica dos participantes. Após sua definição, o instrumento passou por um pré-teste aplicado a 12 indivíduos, quando foi possível detectar falhas, corrigindo-as antes da aplicação final. O período de aplicação do questionário foi entre os dias 03 e 05 de outubro de 2014. Com a finalidade de abranger todos que visitaram o Santuário neste período, os questionários foram aplicados em pontos estratégicos, tais como proximidades das principais capelas, casa das graças e restaurantes, locais que possuem maior movimentação. A coleta foi realizada por três aplicadores, potencializando assim o número de participantes, considerando o curto período de aplicação.

No grupo formado pelos turistas e visitantes, a pesquisa foi abordada com uma amostra cuja técnica é definida como não probabilística por conveniência. Esta tipologia não faz uso de seleção aleatória e fica a cargo do pesquisador decidir os elementos que serão incluídos (MALHOTRA, 2006; PRODANOV; FREITAS, 2013). Em uma amostra não probabilística a margem de erro não é um cálculo estabelecido, já que não permite a inferência do resultado na população (LEVINE et al., 2008; PRODANOV; FREITAS, 2013). Contudo este estudo obteve o número de 162 respondentes em uma população estabelecida como infinita.

Os dados quantitativos gerados foram analisados por meio da técnica da estatística descritiva por distribuição de frequência, de média e desvio padrão 
(MALHOTRA, 2006). Também foi feita a Análise de Componente Principal (ACP) (COOPER; SCHINDLER, 2003), que permitiu inferências em grupos de características específicas componentes da amostra, com relação aos resultados de avaliação do conhecimento e utilização dos canais de comunicação de marketing. Conjuntamente à $A C P$, o Teste- $t$ de amostras independentes para médias também foi realizado. Os resultados foram tabulados através da ferramenta Sphinx Plus ${ }^{2}$ e suas devidas apresentações realizadas em tabelas, gráficos e quadros resumos.

\section{RESULTADOS DO ESTUDO}

Os resultados estão apresentados em etapas que competem os objetivos específicos. A priori é analisada a imagem pretendida por meio dos materiais de divulgação, bem como os discursos dos representantes oficiais emissores da mensagem turística. Juntamente a isso, é apresentada a imagem percebida a partir das experiências dos turistas e visitantes. Conforme critérios de análise mencionados na metodologia, as variáveis observadas foram o emissor, receptor, meio, mensagem e resposta, as quais compõem o processo de comunicação, já referenciados anteriormente, com base em Kotler e Keller (2012).

\section{DESCRIÇÃO DO EMISSOR}

Antes de descrever o emissor propriamente dito (Santuário Santa Paulina), faz-se importante caracterizar o município em que o mesmo se encontra, sendo este parte importante da atração local. O município de Nova Trento está localizado no estado de Santa Catarina, mais precisamente no Vale Europeu. Sua população é estimada em aproximadamente 12.190 habitantes (IBGE, 2010), com grande parte de imigração italiana, motivada pelas férteis terras da região. O turismo religioso e o turismo ecológico têm lugar de destaque na cidade e a cada ano a cidade vem crescendo muito nestes setores. Além do Santuário Santa Paulina, que é um dos principais atrativos da cidade, Nova Trento possui outros atrativos relativos ao turismo religioso, como: Santuário Nossa Senhora do Bom Socorro e mais de 30 capelas e igrejas na cidade. 
Inserido na cidade de Nova Trento, o Santuário Santa Paulina faz parte da Congregação das Irmãzinhas da Imaculada Conceição. Neste complexo, atualmente existe apenas um setor de assessoria de imprensa e uma pessoa responsável pelo marketing, mas toda e qualquer decisão tomada no Santuário passa pelo Departamento de Comunicação e Marketing da congregação, que fica na cidade de Ipiranga em São Paulo. Mesmo em sua sede, segundo aponta a Assessora de Imprensa, Andrieli Minatti, a congregação não utiliza serviços de agência de publicidade, concentrando o desenvolvimento destas atividades através de seu próprio pessoal. Sua programação muitas vezes é conjunta com o poder público local (Prefeitura de Nova Trento). Conforme a Assessora de Imprensa, o santuário, representado pela Diretora Ir. Maria Adelina da Cunha e a prefeitura local, através do Secretário do Turismo e Cultura da cidade, trabalham juntas quando o assunto é divulgação. O propósito é desenvolver parcerias com entidades de turismo da cidade e região.

\section{CANAIS DE COMUNICAÇÃO E MENSAGENS}

OSantuário possui como canais de comunicação o website oficial, uma fanpage no facebook, no twitter e no fliker, transmissões de missas pela TV Aparecida e Rede Século 21, divulgação e transmissões de missas através das rádios locais, anúncios em jornais da região, e ações de mídia impressa e de rua, tais como: flyer, outdoor e placas de indicação. Segundo a assessora do Santuário, além dos canais de comunicação, é realizado um trabalho junto aos coordenadores de peregrinação, aos motoristas e aos donos de empresas de ônibus de peregrinações. Todos eles recebem anualmente o cronograma de eventos do Santuário, além de e-mails e convites via correio para eventos específicos.

Para que a imagem ocupe um lugar distinto e valorizado na mente do consumidor, é necessário que aconteça um esforço de posicionamento por parte da organização, um planejamento (SHIMOYAMA; ZELA, 2002, p. 32). Ruschmann (2005) afirma que, para ter uma comunicação eficaz no mercado turístico, o comunicador (emissor) deve detectar os gostos e as preferências do público-alvo (receptor), criando imagens que influenciem favoravelmente as pessoas, estimulando-as a viajar. Para estabelecer um fluxo de informações nos 
dois sentidos, o feedback é fundamental para o turismo e pode conduzir a uma reformulação dos equipamentos e atividades, permitindo melhor adaptação às necessidades e às expectativas dos turistas.

Em relação aos materiais de divulgação, por meio da observação, foi possível notar a presença de um elemento marcante presente em todas as peças: a imagem da capela (Figura 2).

Este componente pode ser justificado pela estrutura moderna que atrai olhares de todos que visitam o local, tornando-se imprescindível acentuar esse elemento pela tamanha importância que representa ao turismo da região. Grande parte das imagens escolhidas é composta dos atrativos que formam o Santuário. Além dos destaques, os materiais apresentam elementos do roteiro do Santuário, que de alguma forma são relembrados pelos visitantes, como: o Casebre, a Casa das Graças e o Cenário da vida de Santa Paulina.

Figura 2 - Outdoor de divulgação
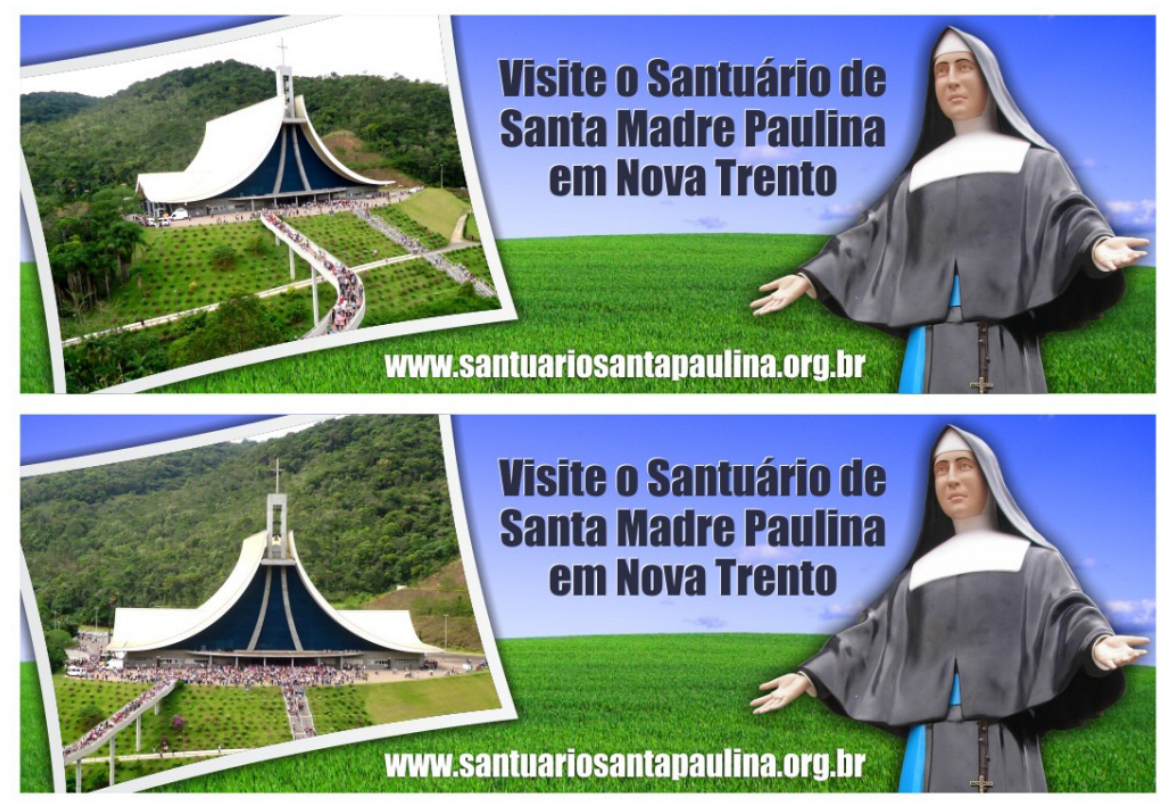

Fonte: Material cedido pelo Santuário 


\section{IMAGEM PERCEBIDA PELO RECEPTOR ATRAVÉS DA PESQUISA}

APLICADA

Os resultados da pesquisa realizada com os turistas e visitantes do Santuário apontam que eles são provenientes de Santa Catarina (87\%), Rio Grande do Sul (8,70\%), Paraná (3,10\%) e São Paulo (1,8\%). Em nível de cidade emissiva, as principais localidades citadas foram as cidades próximas ao Santuário, como São João Batista (6,7\%), Brusque (6,1\%), Tijucas (4,3\%) e Florianópolis (3,1\%). As Regiões Norte e Sul do estado de Santa Catarina foram representadas respectivamente pelas cidades de Joinville (6,1\%), Jaraguá do Sul (5,5\%), Araranguá (4,3\%) e Criciúma (1,8\%). No estado do Paraná e Rio Grande do Sul as principais cidades citadas foram as capitais: Curitiba $(2,5 \%)$ e Porto Alegre $(3,1 \%)$. Já o estado de São Paulo foi representado pela capital São Paulo $(1,2 \%)$ e Bom Retiro (0,6\%).

Ao todo foram citadas 28 cidades diferentes, predominando a região sul e sudeste do Brasil. Comparados estes dados com o estudo da Pesquisa de Demanda da SANTUR (2011), que caracterizou o perfil de visitantes do Santuário, nota-se semelhança em relação aos estados de proveniência dos entrevistados, com supremacia dos catarinenses $(72,75 \%)$, seguido pelos turistas do estado do Paraná (2,65\%). Destaca-se que o período de coleta das pesquisas é distinto, sendo este último nos meses de verão.

A amostra de visitantes apresenta resultado bastante homogêneo para o critério gênero, visto que $80,4 \%$ dos respondentes são mulheres. A faixa etária predominante está entre 50 a 59 anos (30,9\%) e 40 a 49 anos (19,8\%), ocasionando, assim, um efeito significativo para as alternativas casado (46,6\%) e união estável (21,5\%). No que se refere à renda familiar, o percentual de maior destaque ocorreu entre $R \$ 2.901,00$ a $4.344,00$ (37,7\%), seguido de $R \$ 1.449,00$ e $R \$ 2.900,00$ (30,9\%).

Em relação ao perfil da amostra, procurou-se entender qual é o motivo principal da viagem do visitante e, com amparo dos subsídios (motivos), é perceptível que a motivação que mais se destaca é a Religião $(61,1 \%)$ e o Lazer 
(53,7\%). É importante observar que os respondentes poderiam mencionar mais de uma opção e, neste caso, os que apontaram tanto a religião quanto o lazer são apenas $18 \%$ dos integrantes da amostra, o que denota que não estão necessariamente associados.

Quanto à frequência de viagem por motivos religiosos, identificou-se um grande percentual de incidência na opção de quase nunca $(44,4 \%)$ e que, somado aos que nunca (3,7\%), representa praticamente $48 \%$ em que a religião não é um motivo fluente de viagem. Na sequência, a frequência de forma intermediária $(36,4 \%)$ e a segunda opção mais referenciada, somando os que quase sempre e os que sempre viajam, juntos representam (15,40\%). Essa porcentagem evidencia que muitos turistas não se interessam por roteiros turísticos religiosos e, com isso, esse setor tem algumas dificuldades em se desenvolver cada vez mais rápido. Em relação à frequência de visitas no último ano, identificou-se que para $52,5 \%$ dos entrevistados esta era a primeira visita e $22,8 \%$, a segunda vez. Apesar de muitos entrevistados afirmarem que visitaram o Santuário no último ano apenas uma vez, esse baixo nível de visitas não está relacionado à falta de interesse em visitá-lo novamente.

\section{PERCEPÇÃO DA COMUNICAÇÃO DE MARKETING}

Os respondentes foram questionados sobre como obtiveram conhecimento sobre o Santuário. É possível perceber que a comunicação realizada por meio de seus visitantes (Indicação) é bastante forte e obteve o maior percentual (36,4\%) no aspecto relacionado à como o respondente conheceu o Santuário. Esta informação caracteriza que os turistas, em sua maioria, têm aprovado suas experiências no local e recomendado para seus conhecidos. É importante ressaltar que o respondente poderia mencionar mais de uma forma entre aquelas que Ihe foram apresentadas, assim, o item "moro na região" também se destacou e apresentou um percentual de 34,6\%, apontando que o público local valoriza o produto regional e escolhe destinos próximos para a visitação.

Apesar de os meios de comunicação promovidos diretamente pela entidade promotora da entidade religiosa terem representado um impacto reduzido, os 
mesmos existem e cumprem papel importante na formação de sua imagem. Com base nisto, foi solicitado aos participantes do estudo que avaliassem seu conhecimento e nível de utilização dos meios de comunicação utilizados pelo santuário. A escala proposta de 5 pontos foi organizada da seguinte forma: desconheço sua existência (zero); conheço, mas não utilizo (1); conheço, mas utilizo pouco (2); conheço e utilizo quase sempre (3); conheço e utilizo sempre (4). Na Tabela 1 esses resultados são agrupados, considerando a distribuiç̧ão de frequência, a média e o desvio padrão.

O atendimento por meio do telefone teve a indicação de 94,40\% dos entrevistados que afirmaram não ter nenhum conhecimento sobre a existência do mesmo, resultando em uma média de 0,07 ponto com o menor desvio padrão entre os canais analisados $(0,32)$. Supõe-se que isso aconteça, pois os respondentes nunca necessitaram manter contato com o santuário. Quando questionados sobre o conhecimento da TV Santuário, 41,4\% dos entrevistados responderam que a conhecem, mas não utilizam. Há também os 39,50\% que afirmaram que desconhecem a sua existência. Em relação conhecimento e utilização, este canal foi o que apresentou a maior média $(0,95)$, porém com desvio padrão também mais acentuado $(0,95)$.

Tabela 1 - Análise do conhecimento e uso dos meios de comunicação do Santuário.

\begin{tabular}{cccccccc}
\hline Canais analisados & 0 & 1 & 2 & 3 & 4 & Média & $\begin{array}{c}\text { Desvio } \\
\text { Padrão }\end{array}$ \\
\hline Atendimento telefônico & $94,40 \%$ & $4,90 \%$ & $0,00 \%$ & $0,60 \%$ & $0,00 \%$ & 0,07 & 0,32 \\
TV Santuário & $39,50 \%$ & $41,40 \%$ & $11,70 \%$ & $5,60 \%$ & $1,90 \%$ & 0,89 & 0,95 \\
Revista Santuário & $68,50 \%$ & $31,50 \%$ & $0,00 \%$ & $0,00 \%$ & $0,00 \%$ & 0,31 & 0,47 \\
Rádio Santuário & $69,10 \%$ & $30,90 \%$ & $0,00 \%$ & $0,00 \%$ & $0,00 \%$ & 0,31 & 0,46 \\
Jornal Santuário & $69,80 \%$ & $30,20 \%$ & $0,00 \%$ & $0,00 \%$ & $0,00 \%$ & 0,3 & 0,46 \\
Website do Santuário & $38,30 \%$ & $41,40 \%$ & $19,10 \%$ & $1,20 \%$ & $0,00 \%$ & 0,83 & 0,77 \\
Fanpage do Santuário & $45,70 \%$ & $40,10 \%$ & $13,00 \%$ & $1,20 \%$ & $0,00 \%$ & 0,7 & 0,74 \\
Materiais impressos do & $22,20 \%$ & $48,10 \%$ & $29,00 \%$ & $0,60 \%$ & $0,00 \%$ & 1,08 & 0,73 \\
Santuário & $17,30 \%$ & $49,40 \%$ & $27,20 \%$ & $4,30 \%$ & $1,90 \%$ & 1,24 & 0,85 \\
\hline Placas indicativas e de rua &
\end{tabular}

Fonte: Dados da pesquisa (2014).

Em relação ao meio de comunicação Revista, 68,50\% dos entrevistados afirmaram desconhecer da sua existência e 31,50\% disseram que apesar de 
a conhecerem, não a utilizam. Os resultados foram similares na comunicação via Rádio, em que 69,10\% mencionaram que desconhecem sua existência e $31,50 \%$, apesar de conhecerem, afirmaram que não o utilizam. O Jornal do Santuário também teve resultado semelhante, já que 69,8\% disseram não ter conhecimento. Essa similaridade de resultados também foi apurada na média, que oscilou entre os três canais entre 0,3 e 0,31 ponto, com desvio padrão entre 0,47 e 0,46.

Quanto ao Website, $41,40 \%$ dos entrevistados afirmaram que conhecem, porém não o utilizam, assim como a Fanpage do Santuário, com 45,70\% que afirmaram desconhecer a sua existência e 40,10\% que não a utilizam. Respectivamente, estes canais de comunicação na relação conhecimento e utilização obtiveram 0,83 ponto e 0,87 ponto de média. Percebe-se então que, apesar do crescimento da utilização das redes sociais, muitos entrevistados não têm interesse em usufruir desse meio.

Já em relação ao material impresso, a maioria dos entrevistados afirmou que, apesar de conhecer, não utiliza (48,1\%) ou utiliza pouco (29\%). Ademais, no que se refere às placas de indicação do Santuário, 48,1\% disseram que não utilizam e $29 \%$ afirmaram que utilizam pouco. Neste último, o índice de utilização pode ser um indicativo do perfil do respondente, visto que a maioria dos entrevistados reside em cidades próximas e já conhece o lugar. Contudo, foi o canal que atingiu o maior valor médio entre os pesquisados, com 1,24 ponto e desvio padrão de 0,85 .

Através dos dados apresentados sobre o conhecimento dos meios de comunicação, nota-se que grande parte dos entrevistados desconhece ou não utiliza os meios disponibilizados. Apesar desta tendência registrada, percebe-se que esse resultado sofre alterações quando são observadas as médias comparadas com o perfil da amostra. Neste sentido destaca-se a variável faixa etária, analisada por meio de uma ACP, cujos resultados são apresentados no Gráfico 1.

Destaca-se que os canais de comunicação WebSite e Fanpage do Santuário atingiram maior utilização entre os respondentes com 15 a 19 anos e 20 a 29 anos, com média de 1,4 e 1,2 ponto para o primeiro e 1,4 e 1,15 para o segundo, respectivamente superiores a média geral encontrada, que foi de 0,83 
ponto e 0,7 ponto. Enquanto isso, a Rádio, o Jornal e a Revista Santuário são mais significativos entre os membros da amostra entre 30 a 39 anos. Repercute também a TV Santuário junto aos participantes com 60 a 69 anos e 70 ou mais anos, com 1,16 ponto e 1,38 ponto, superior aos 0,89 ponto de média entre todas as faixas etárias.

Gráfico 1 - Análise de componentes principais dos Canais de Comunicação pela faixa etária.

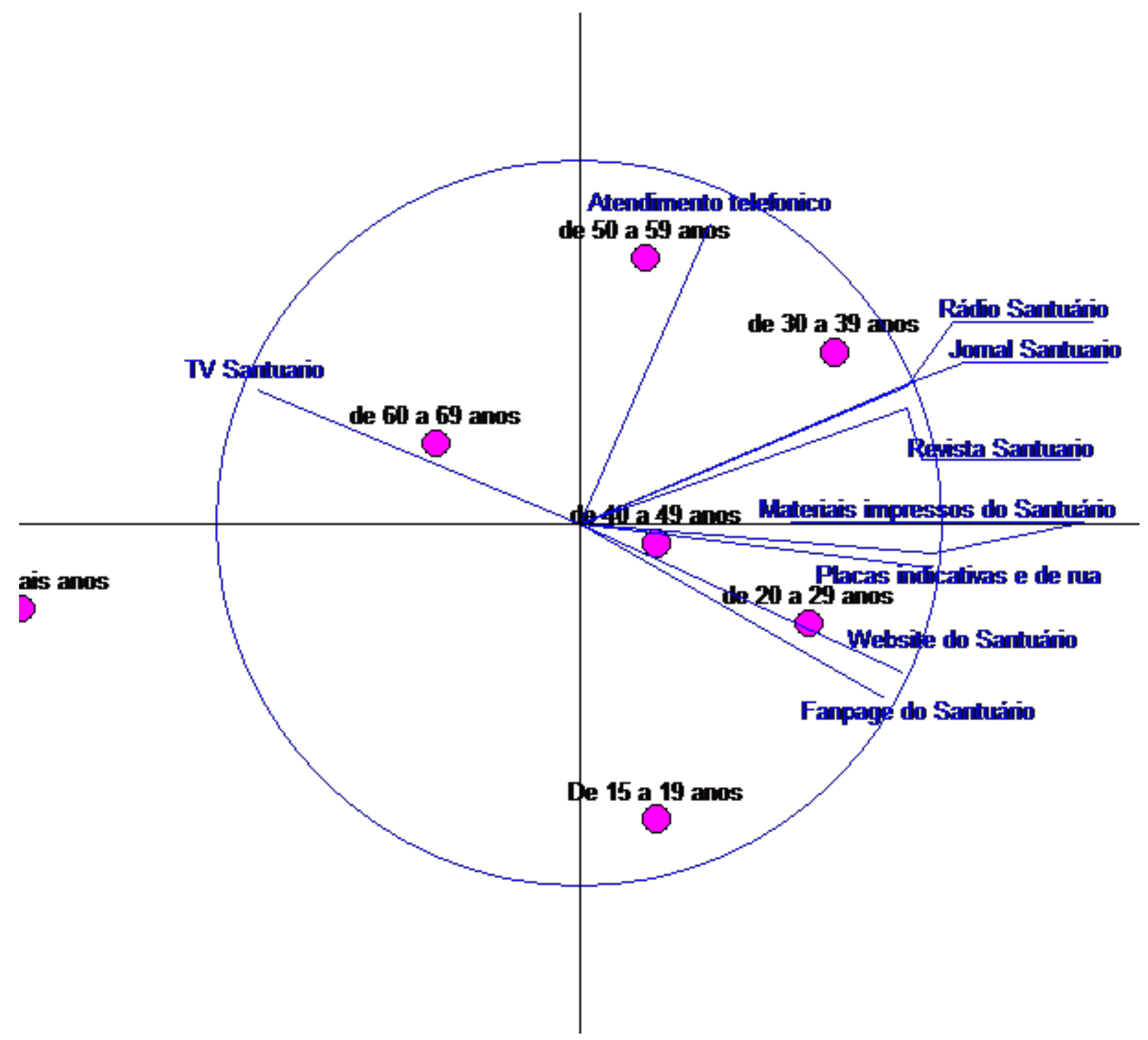

Fonte: Dados da pesquisa (2014).

Quando relacionado o gênero com os canais de comunicação, o desconhecimento por parte dos respondentes masculinos é mais acentuado, já que em todos os canais a média feminina alcançada indica que o conhecimento foi superior. A diferença se acentua principalmente nos canais TV e Fanpage, 
correspondentes às médias por categorias significativamente diferentes (Teste-t) do conjunto da amostra (ao risco de 95\%). Os resultados vão ao encontro disto nestes dois casos - para a TV com 1-p = 97,60\% - e Fanpage com 1-p = 99,12\%. Esse resultado, conforme indicam Churchill, Brown e Suter (2011), é consideravelmente menor que os padrões considerados para se alcançar a significância estatística.

Em relação ao nível de satisfação do material institucional do Santuário, inicialmente observou-se que 9,3\% da amostra indicou não conhecer nenhum material. Entre os que conhecem ( $n=147)$, nota-se que $43,5 \%$ afirmaram considerar os mesmos como satisfatórios e 34\% apenas regular. Dessa forma, a avaliação do material atingiu apenas $21,7 \%$ de indicação, proveniente de avaliação como Bom (12,2\%) e Ótimo (9,5\%).

Quando questionados se gostariam de receber informações do santuário através dos meios de comunicação citados no questionário, $65 \%$ afirmaram que não. Entre os demais (34,4\%), 25\% gostariam que as informações ocorressem através de jornal, TV (23,2\%), Website (21,40\%) ou Rádio (16,1\%). Já os resultados em relação aos materiais impressos $(7,1 \%)$, a revista do santuário $(5,4 \%)$ e o facebook (1,8\%) foram pouco representativos. A partir da análise dos dados foi possível identificar também que a divulgação sobre a visita ao Santuário ocorre por meio de maneira informal ("boca a boca"), sendo que $70,4 \%$ afirmaram que provavelmente falariam sobre a sua vinda ao local e $17,30 \%$ com certeza falaria.

\section{CORRELAÇÃO DOS RESULTADOS COM O MODELO DO PROCESSO DE COMUNICAÇÃO}

Conforme citado na fundamentação teórica, o modelo apresentado na Figura 1 (p. 5) apresenta os nove principais elementos da comunicação, os quais também estão relacionados à comunicação de marketing. Seu conhecimento e entendimento possibilitam que esse processo seja exercido de modo eficaz, tornando possível o êxito nesse âmbito dentro e fora da organização. 
Quadro 1 - Processo de comunicação conforme emissor e receptor do Santuário Santa Paulina

\begin{tabular}{|c|c|}
\hline \multicolumn{2}{|r|}{ Elementos investigados } \\
\hline Emissor & Receptor \\
\hline Santuário Santa Paulina & $\begin{array}{l}\text { Público frequentador formado por famílias e pessoas da melhor idade } \\
\text { (conforme dados do Santuário). Em relação à pesquisa, o público é } \\
\text { constituído principalmente de mulheres, entre } 40 \text { a } 59 \text { anos. }\end{array}$ \\
\hline Meio utilizado & Meio de alcance \\
\hline $\begin{array}{l}\text { Atendimento telefônico } \\
\text { TV Santuário } \\
\text { Rádio Santuário } \\
\text { Jornal Santuário } \\
\text { Revista Santuário } \\
\text { Web Santuário } \\
\text { Fanpage Santuário } \\
\text { Material de divulgação } \\
\text { Santuário } \\
\text { Placas de indicação e de rua } \\
\text { Contato com os guias }\end{array}$ & $\begin{array}{c}\text { Meio desconhecido }(94,40 \%) \\
\text { Muitos conhecem, porém não utilizam (41,40\%) } \\
\text { Meio desconhecido }(69,10 \%) \\
\text { Meio desconhecido }(69,80 \%) \\
\text { Meio desconhecido }(68,50 \%) \\
\text { Muitos conhecem, porém poucos utilizam }(41,40 \%) \\
\text { Alguns desconhecem, porém os que conhecem não utilizam }(45,70 \%) \\
\text { Muitos conhecem, porém poucos utilizam }(48,10 \%) \\
\text { Muitos conhecem, porém poucos utilizam }(49,40 \%) \\
-\end{array}$ \\
\hline \multicolumn{2}{|r|}{ Meio ideal } \\
\hline \multicolumn{2}{|c|}{$\begin{array}{l}\text { Entre os que gostariam de receber informações do Santuário (34,4\%), jornal, TV e o Website são os mais } \\
\text { indicados. }\end{array}$} \\
\hline \multicolumn{2}{|r|}{ Mensagem transmitida } \\
\hline \multicolumn{2}{|c|}{$\begin{array}{l}\text { A mensagem que o Santuário transmite ao seu público é a história de Santa Paulina, através dos } \\
\text { atrativos apresentados nos materiais de divulgação, fazendo com o que o turista tenha interesse em } \\
\text { conhecer um pouco mais da sua história e do santuário. }\end{array}$} \\
\hline \multicolumn{2}{|r|}{ Resposta } \\
\hline $\begin{array}{l}\text { Em relação ao question } \\
\text { os mesmos não têm int€ }\end{array}$ & $\begin{array}{l}\text { aplicado, percebe-se que muitos conhecem o Santuário. Entretanto, } \\
\text { se em buscar informações nos meios de divulgação promovidos pelo } \\
\text { Santuário. }\end{array}$ \\
\hline
\end{tabular}

Fonte: dados da pesquisa (2014).

De acordo com os resultados apresentados no decorrer da análise, percebese que o Santuário, apesar de ser conhecido mundialmente, não está impactando turistas e potenciais turistas com as suas ações de comunicação. Isso leva a uma reflexão dos componentes do processo de comunicação, a fim de evidenciar suas lacunas. Conforme interpretação dos dados anteriormente apresentados no quadro 1 , seguem as considerações da reflexão proposta, feitos a partir de alguns dos elementos do processo de comunicação. 


\section{CONSIDERAÇÕES FINAIS}

À medida que o turismo assume importante força econômica e auxilia no desenvolvimento de diversas localidades, torna-se fundamental a criação de estudos com a finalidade de compreender melhor o funcionamento do setor e suas peculiaridades. Com isso, em relação à competitividade do mercado turístico no setor religioso, destaca-se a importância da administração da imagem local, tornando-a única e diferenciada.

Para tal ação, torna-se necessária a criação de um direcionamento estratégico que posicione e construa uma ideia coesa entre a oferta apresentada e o mercado alvo pretendido. Dessa forma, para que o posicionamento pretendido seja projetado na mente de um turista potencial, é necessário que exista um investimento em comunicação para a contribuição da formação desse posicionamento.

Neste âmbito, este estudo analisou o processo de comunicação de marketing junto aos visitantes do Santuário Santa Paulina. Sua operacionalização ocorreu por meio da descrição do perfil do emissor e do receptor; da identificação dos meios e mensagens transmitidas; e da avaliação dos impactos provocados pela comunicação de marketing no turismo religioso em relação ao receptor.

Quanto ao emissor, o Santuário Santa Paulina vem desenvolvendo sua comunicação a partir de uma estrutura enxuta, centrada na figura de uma assessora que tem o suporte da unidade central da Congregação das Irmãzinhas da Imaculada Conceição. Não realizam trabalhos com agência de publicidade e seus esforços normalmente são em conjunto com a secretaria de turismo do município de Nova Trento.

Logo, com base nos resultados, a priori se destaca a falta de comunicação efetiva que o Santuário possui para alcançar o público potencial. Considera-se também que o mesmo é bastante disperso geograficamente, o que implica um maior desafio. Além disso, os materiais de divulgação apresentados pela assessoria do Santuário apontam que os turistas e visitantes não buscam conhecer o que o Santuário oferece. Percebe-se então que, possivelmente, 
a ausência de uma equipe de comunicação específica no Santuário está ocasionando este resultado.

Ademais, a pesquisa com os turistas e visitantes expôs informações que aludem para certa divergência da imagem do Santuário Santa Paulina. O estudo apresenta que $36,2 \%$ dos respondentes conheceram o Santuário por meio de indicação, e a minoria conheceu o mesmo por meio de meios de comunicação (12,3\%). Dessa forma, os resultados aferem que a comunicação apresentada pelo Santuário não está sendo eficaz. Quando foi questionado se havia interesse em receber informações do Santuário, a grande maioria respondeu que não tem interesse (65\%) e apenas $(34,4 \%)$ afirmaram que gostariam de receber informações.

O processo de comunicação de marketing do Santuário em relação aos turistas está bem esclarecido. Existe a prioridade em enfatizar a história de Santa Paulina no processo de comunicação, fazendo com que de alguma maneira a mensagem transmitida seja fixada por meio das imagens marcantes do Santuário.

No que compete às limitações deste estudo, destaca-se que a amostra não probabilística por conveniência acarretou a impossibilidade de inferir os resultados alcançados no total da população. Existem também as limitações referentes ao período da coleta de dados, que acabou ocasionando uma amostra mais homogênea. Em relação a novas pesquisas, sugere-se um entendimento mais aprofundado de cada uma das mídias utilizadas, considerando a identificação dos motivos de baixa penetração das mesmas. Outra sugestão é identificar qual é o público atualmente atingido pelos meios, correlacionando com o índice de visita ao santuário. Ao aprofundar-se a contribuição pode direcionar a criação de ações que gerem resultados mais eficazes e atrair mais visitantes para o local.

REFERÊNCIAS

AAKER, D. A.; KUMAR, V.; DAY, G. S. Pesquisa de Marketing. 2. ed. São Paulo: Atlas, 2004.

AMERICAN MARKETING ASSOCIATION. Definição de Marketing. Disponível em: < http:// www.marketingpower.com/AboutAMA/Pages/DefinitionofMarketing.aspx>. Acesso em: 22 de agosto de 2014. 
AVRAHAM, E.; KETTER, E. Media Strategies for Marketing Places in Crisis: Improving the Image of Cities, Countries and Tourism Destinations. Oxforf: Elsevier Inc, 2008. Disponível em: <http://goo.gl/RTQ45O>. Acesso em: 04 jul. 2015.

BARDIN, L. Análise de conteúdo. 7. ed. Lisboa: Edições 70, 2009.

BRASIL. SANTUARIO SANTA PAULINA. Santuário: um pouco da História. 2014. Disponível em: <http://www.santuariosantapaulina.org.br/index.php/o-santuario/historia>. Acesso em: 23 de agosto de 2014.

BRASIL. Ministério do Turismo (Org.) Segmentação do turismo e o mercado. Brasília: Ministério do Turismo, 2010. 176 p.

CACHO, A; AZEVEDO, F. O Turismo no Contexto da Sociedade Informacional. Revista Brasileira de Pesquisa em Turismo. Brasil, v. 4, n. 2, p. 31-48. ago. 2010. Disponível em: <goo.gl/mlbFIL >. Acesso em: 08 jul. 2014

CARVALHO, R; VIANA, M. Somos o que consumimos: aspectos identitários e turismo contemporâneo. Revista Turismo - Visão e Ação. Balneário Camboriú, v.16, n.3, p. 690 709. Set-Dez.2014. Disponível em < http://goo.gl/BVxPvx>. Acesso em: 24 jul.2014

CARVAO, S. Tendências do Turismo Internacional. Exedra, Portugal, v. 4, n. 0, p.17-32, 2010. Disponível em: <http://goo.gl/RTQ45O>. Acesso em: 04 jul. 2015.

CHURCHILL, G.A.; BROWN, T.J.; SUTER, T.A. Pesquisa básica de Marketing. 7. ed. São Paulo: Cengage Learning, 2011.

COBRA, M. Marketing Básico. 4. ed. São Paulo: Atlas, 1997.

COOPER, D.R.; SCHINDLER, P. S. Métodos de Pesquisa em Administração. 7. ed. Porto Alegre: Bookman, 2003.

DE LA TORRE, G.; NARANJO, L.; CÁRDENAS, R.. Etapas Del Ciclo de Vida En El Desarrollo Del Turismo Religioso: Una Comparación de Estudios de Caso. Cuadernos de Turismo, Murcia, v. 0, n. 30, p.241-266, 2012. Disponível em: <http://goo.gl/sVZc30>. Acesso em: 02 jul. 2015.

DIAS, R.. O turismo religioso como segmento do mercado turístico. In: DIAS, Reinaldo; SILVEIRA, Emerson J. S. da. (Orgs). Turismo religioso: ensaios e reflexões. Campinas: Alínea, 2003.

DRULE, A; CHIS, A; BACILA, M; CIORNEA, R. A new perspective of non-religious motivations of visitors to sacred sites: evidence from Romania. Elsevir. Turquey, v. 62, n. 24, p. 431- 435. out. 2012 
FERREIRA, E.; SANTOS, S. R. Roteiro Turístico pelas Igrejas Católicas do Centro Histórico de São Luís (MA). In: SEMINÁRIO DE PESQUISA EM TURISMO DO MERCOSUL, 6., 2010, Caxias do Sul. Anais... Caxias do Sul: Universidade de Caxias do Sul, 2010. p. 01 - 17. Disponível em: <goo.gl/39fDxO>. Acesso em: 01 jul. 2015.

IAPICHINO, Donatella Armeli. Caratteristiche di Personalità e Motivacione Turistica Alla Scelta Del Viaggio di Tipo Religioso. 152 f. Tese (Doutorado) - Curso de Turismo, Dipartimento di Metodi Quantitativi Per Le Scienze Umane, Università Degli Studi di Palermo, Palermo, 2010. Disponível em: <goo.gl/ONBkFD>. Acesso em: 02 jul. 2015.

KOTLER, P. Marketing para o século XXI: como criar, conquistar e dominar mercados. São Paulo, SP: Agir, 2009. 303 p.

KOTLER, P.; KELLER, K. L. Administração de Marketing. 12. ed. São Paulo: Pearson, 2012.

JALUSKA, T; JUNQUEIRA, S. A utilização dos espaços sagrados pelo turismo religioso e suas possibilidades como ferramenta auxiliar para o estabelecimento do diálogo entre as nações. Revista Turismo - Visão e Ação. Balneário Camboriú, v.14, n.3, p. 337 - 348. SetDez.2012. Disponível em < http://goo.gl/o7Ba5O>. Acesso em: 24 jul.2014

LEVINE, D. M. et al. Estatística: teoria e aplicações. 5. ed. Rio de Janeiro: LTC, 2008.752 p.

MALHOTRA, N.. Pesquisa de Marketing: Uma Orientação Aplicada. 4. ed. São Paulo: Bookman, 2006.

MIDDLETON, V.T.C.; CLARKE, J. Marketing de Turismo: Teoria \& Prática. Rio de Janeiro: Campus, 2002.

MINATTI, A.. Dados do número de visitantes ao Santuário Santa Paulina. [mensagem pessoal] Mensagem recebida por: <Letícia Caetano>. em: 22 ago. 2014. Acesso em: 18 ago. 2014.

MORRISON, A. M.. Marketing de Hospitalidade e Turismo. 4. ed. São Paulo: Cengage Learning, 2012.

OLIVEIRA, C. D. M. de. Turismo Religioso. São Paulo: Aleph, 2004.

PRODANOV, C. C.; FREITAS, E. C. de. Metodologia do trabalho científico: métodos e técnicas da pesquisa e do trabalho acadêmico. 2. ed. Novo Hamburgo: Feevale, 2013. 277 p. Disponível em: <http://docente.ifrn.edu.br/valcinetemacedo/disciplinas/metodologiado-trabalho-cientifico/e-book-mtc>. Acesso em: 10 out. 2014 
REFKALEFSKY, E.. Comunicação e Marketing Religioso: definições conceituais. 2012. 150 f. Tese (Doutorado) - Curso de Turismo, Escola de Comunicação da Universidade Federal do Rio de Janeiro (eco/ufrj), Rio de Janeiro, 2012.

RIBEIRO, H.. Andar com fé e o sentido do chegar. 2003. 3 v. Monografia (Especialização) - Curso de Turismo, Instituto Virtual do Turismo, Rio de Janeiro, 2003.

RUSCHMANN, D. Marketing turístico: um enfoque promocional. 2. Ed. Campinas, SP: Papirus. 2000.

SANTUR . Pesquisa do turismo religioso: no Santuário Santa Paulina. 2011. Disponível em: < file:///C:/Users/Marcelo/Downloads/religioso2011_v2\%20(1).pdf>. Acesso em: 15 de outubro de 2014.

SHARPLEY, R.; TELFER, D. Tourism and Development: Concepts and Issues. 2. ed. India: Channel View, 2015. Disponível em: <https://goo.gl/4DTqaE>. Acesso em: 01 jul. 2015.

SOLOMON, M.R; RIBEIRO, L.B. O comportamento do consumidor: comprando, possuindo e sendo.9. ed. Porto Alegre: Bookman, 2011.

SWARBROOKE, J.; HORNER, S. O comportamento do consumidor no turismo. Trad. Saulo Krieger. São Paulo: Aleph, 2002 (Turismo).

Trigo, L.; Almeida, R.; Leite, E.; Malcher, M. Aprendiz de Lazer e Turismo. Ed. rev. e ampl. São Paulo: IPSIS. 2007.

VAZ, G.N.. Marketing Turístico: Receptivo e Emissivo: Um roteiro estratégico para projetos mercadológicos públicos e privados. São Paulo: Pioneira, 1999. 